\title{
PENETAPAN AHLI WARIS PENERIMA SANTUNAN JASA RAHARJA DALAM PP NO. 18 TAHUN 1965
}

\author{
Zakiyatul Ulya \\ Sekolah Tinggi Agama Islam Sunan Giri Bojonegoro. \\ E-mail: ulyaelzakiya@gmail.com
}

\begin{abstract}
This bibliographical research aims to answer the questions of how the determination of the heirs as receivers of Jasa Raharja compensation stated in PP (Peraturan Pemerintab/Government Regulation) No. 18 Year 1965 and how the Islamic law perspective against the determination of the heirs as receivers of Jasa Raharja compensation. The data that obtained by documentation technique are further analyzed by descriptive method and deductive mindset. The research concludes that according to PP No. 18 Year 1965, the heirs are children, widow/widower, and/ or the parents of the victim died of road traffic accident with the rule of the receipt and payment of compensation starting from the legitimate widow/widower, legal children, and legal parents. Thus, it can be said that the determination of the heirs within such regulation does not fully implement the provision of the Islamic inheritance system since it only provides Jasa Raharja compensation as a part of estate to the heirs who cannot be stunted (mabjub hirman), such as widow/widower, children, and parents. However, if it is viewed from the origin compensation of Jasa Raharja that is not coming from the victim but gathered from the owners of the transport equipment, it can be quite fair when the compensation is only given to the nearest heirs.
\end{abstract}

Abstrak: Tulisan ini merupakan hasil penelitian pustaka (library research) yang bertujuan untuk menjawab pertanyaan tentang bagaimana penetapan ahli waris penerima santunan Jasa Raharja dalam PP No. 18 Tahun 1965 dan bagaimana analisis Hukum Islam terhadap penetapan ahli waris penerima santunan Jasa Raharja tersebut. Data penelitian dihimpun dengan menggunakan teknik dokumentasi yang selanjutnya dianalisis menggunakan metode deskriptif analisis dengan pola pikir deduktif. Hasil penelitian menyimpulkan bahwa menurut PP No. 18 Tahun 1965, ahli waris hanyalah anak-anak, janda/ duda, dan/ atau orang tua dari korban mati kecelakaan lalu lintas jalan dengan aturan penerimaan pembayaran santunan dimulai dari jandanya/ dudanya yang sah, kemudian anak-anaknya yang sah dan diakhiri orang tuanya yang sah. Dengan demikian, dapat dikatakan bahwa penetapan ahli waris dalam peraturan tersebut tidak sepenuhnya menerapkan ketentuan hukum kewarisan Islam karena hanya memberikan santunan Jasa Raharja yang merupakan bagian harta waris kepada golongan ahli waris yang

\section{AL-HUKAMA}

The Indonesian Journal of Islamic Family Law

Volume 06, Nomor 02, Desember 2016; ISSN:2089-7480 
tidak bisa ter-hijab hirman, yaitu janda/ duda, anak-anak serta orang tua. Meskipun begitu, jika dilihat dari asal santunan Jasa Raharja yang bukan dari korban, namun terhimpun dari para pemilik/ pengusaha alat angkutan lalu lintas jalan, maka dapat dikatakan cukup adil jika santunan tersebut hanya diberikan kepada ahli waris sedarah yang terdekat saja.

Kata Kunci: ahli waris, santunan Jasa Raharja, PP No. 18 Tahun 1965

\section{Pendahuluan}

Setiap manusia sudah pasti akan mengalami peristiwa kelahiran dan kematian. Peristiwa kelahiran akan menimbulkan akibat-akibat hukum, seperti timbulnya hubungan hukum dengan masyarakat sekitarnya serta timbulnya hak dan kewajiban pada dirinya. Peristiwa kematian yang bersifat personal ternyata akan menimbulkan akibat hukum kepada orang lain terutama pada pihak keluarganya dan pihak-pihak tertentu yang mempunyai hubungan dengan orang tersebut semasa hidupnya.

Hal di atas dapat dilihat dengan jelas pada masalah kewarisan yang menyebabkan harta yang dimiliki oleh orang yang meninggal beralih kepada pihak lain yang masih hidup, yaitu kepada orangorang yang telah ditetapkan sebagai pihak penerimanya. Hukum Islam maupun hukum Hindu telah mengatur secara rinci berbagai persoalan mengenai kewarisan, yang an meliputi sebab-sebab lain meliputi sebab mendapatkan dan tidak mendapatkan harta warisan, penggolongan ahli waris dan bagiannya masing-masing beserta tata cara pembagian harta warisan.

Meskipun begitu lengkapnya Islam mengatur permasalahan waris, tidak semua aturan kewarisan Islam tersebut digunakan di Negara Indonesia karena Negara Indonesia bukanlah Negara Islam yang mengikuti ketentuan hukum Islam secara mutlak. Selain itu juga, dalam sejarah perjalanan bangsa Indonesia, berbagai hukum kewarisan selain hukum Islam pernah berlaku, yang diantaranya adalah hukum adat dan hukum barat yaitu berupa Kitab Undangundang Hukum Perdata yang tidak lain juga menjadi sumber acuan dalam pembuatan peraturan baru, sehingga tidak sedikit peraturan Negara Indonesia yang muncul akhirnya berbeda dengan ketentuan Islam.

Salah satu aturan yang berbeda dengan ketentuan Islam datang dari PP No. 18 Tahun 1965, yaitu sebuah peraturan yang 
berisi tentang Ketentuan-ketentuan Pelaksanaan Dana Kecelakaan Lalu Lintas Jalan yang tidak lain merupakan peraturan pelaksana dari UU No. 34 Tahun 1964. Pengelolaan dan penyaluran dana Kecelakaan Lalu Lintas Jalan tersebut diamanatkan kepada Jasa Raharja, sehingga uang yang disalurkan kepada korban/ ahli waris korban kecelakaan lalu lintas biasa dikenal dengan santunan Jasa Raharja.

Perbedaan yang dimaksud di atas, terlihat jelas dalam hal penetapan ahli waris penerima santunan jasa raharja yang salah satunya terwakili dalam pasal 12 PP No. PP No. 18 Tahun 1965 ini yang menyebutkan bahwa yang dimaksud ahli waris hanyalah anakanak, janda/ duda, dan/ atau orang-tua dari korban mati kecelakaan lalu-lintas jalan. ${ }^{1}$ Lantas bagaimana hukum Islam memandang ketentuan dalam penetapan ahli waris penerima santunan jasa raharja dalam PP No. 18 tahun 1965 akan dibahas lebih detail dalam artikel ini.

\section{Metodologi Penelitian}

Penelitian ini merupakan studi kepustakaan (library research) yang menjadikan PP No. PP No. 18 Tahun 1965 sebagai obyek kajiannya yang terfokus pada penetapan ahli waris penerima santunan Jasa Raharja. Teknik pengumpulan data yang digunakan dalam penelitian ini adalah teknik dokumentasi yaitu mengumpulkan dokumen-dokumen tertulis, baik yang berbentuk hard copy maupun soft copy yang berhubungan dengan penetapan ahli waris penerima santunan Jasa Raharja.

Data yang terkumpul lalu dianalisis menggunakan metode deskriptif analisis dengan pola pikir deduktif, yaitu teknik analisis menggambarkan terlebih dahulu ketentuan-ketentuan tentang pelaksanaan Dana Kecelakaan Lalu Lintas Jalan yang terdapat dalam PP No. 18 Tahun 1965 yang meliputi ketentuan penetapan ahli waris penerima santunan Jasa Raharja beserta ketentuan dana

1 Presiden Republik Indonesia, "Peraturan Pemerintah Republik Indonesia Nomor 18 Tahun 1965 Tentang Ketentuan-ketentuan Pelaksanaan Dana Kecelakaan Lalu Lintas Jalan," dalam http://dapp.bappenas.go.id/website/peraturan/file/pdf/PP_1965_018.pdf (22 Oktober 2011), 2. 
santunannya, kemudian dianalisis menggunakan teori kewarisan Islam, sehingga diperoleh kesimpulan mengenai sesuai atau tidaknya ketentuan tersebut dengan ketentuan yang ada dalam hukum Islam.

\section{Kewarisan dalam Hukum Islam}

Kewarisan menyebabkan harta yang dimiliki oleh orang yang meninggal beralih kepada pihak lain yang masih hidup, yaitu kepada orang-orang yang telah ditetapkan sebagai pihak penerimanya. Adapun proses peralihan harta tersebut diatur oleh Hukum Waris/ Ilmu Faraid\}/ Figh Mawaris|. ${ }^{2}$ Pewarisan harta tersebut meliputi semua harta yang dimiliki baik yang berkaitan dengan harta kekayaan maupun hak-hak lain yang tergantung kepadanya, misalnya utang piutang dan hak ganti rugi. ${ }^{3}$

Adanya perbedaan dalam penamaan tersebut tidak lain terjadi karena perbedaan arah yang dijadikan titik utama dalam pembahasan. Penyebutan faraid\} didasarkan pada bagian yang diterima oleh ahli waris. Pemakaian kata waris| lebih merujuk kepada orang yang menerima harta warisan. Sedangkan, penggunaan kata mawaris | lebih melihat kepada obyek dari hukum ini yaitu harta yang beralih kepada ahli waris yang masih hidup atau yang lebih dikenal dengan maurus | (harta benda yang ditinggalkan oleh si mayit yang akan dibagi oleh para ahli waris setelah diambil untuk biaya-biaya perawatan, melunasi hutang, dan melaksanakan wasiat). ${ }^{4}$

Adapun penyebutan dalam istilah hukum yang baku dan digunakan dalam kajian hukum Islam adalah $H\}$ ukm al-Waris $\mid$. Hukum kewarisan Islam biasanya diartikan sebagai seperangkat peraturan tertulis berdasarkan wahyu Allah dan sunnah Nabi tentang peralihan harta dari yang telah mati kepada yang masih

2 Suparman Usman dan Yusuf Somawinata, Fiqih Mawaris Hukum; Kewarisan Islam, cet. II (Jakarta: Gaya Media Pratama, 2002), 13.

3 Abdur Rahman I. Doi, Syariab II; Hudud dan Kewarisan, terj. Zaimuddin, et al, cet. I (Jakarta: PT Raja Grafindo Persada, 1996), 98.

${ }^{4}$ Moh. Muhibbin dan Abdul Wahid, Hukum Kewarisan Islam; Sebagai Pembaharuan Hukum Positif di Indonesia (Jakarta: Sinar Grafika, 2009), 57. 
hidup, yang diakui dan diyakini berlaku dan mengikat untuk semua yang beragama Islam. ${ }^{5}$

Pada masa Jahiliyah harta waris tidak diberikan kepada kaum perempuan dan anak-anak dari orang yang meninggal, mereka beranggapan bahwa hanya orang yang pergi ke medan perang yang berhak mendapatkan warisan. ${ }^{6}$ Bahkan janda perempuan dari orang yang telah meninggal termasuk bagian dari harta peninggalan yang dapat diwarisi oleh pihak keluarga yang masih hidup.

Keadaan waris Jahiliyah kemudian berubah pada masa umat Islam hijrah ke Madinah, yaitu dengan didasarkannya hukum waris pada hubungan keislaman. Orang Islam dari Madinah dapat mewarisi harta peninggalan saudaranya dari Makkah yang beragama Islam. Hal tersebut berlangsung sampai turunnya surat al-'Anfal ayat 75 yang mengubah peraturan kewarisan yang berdasarkan persaudaraan Islam menuju aturan yang berdasarkan garis kekerabatan dalam Islam. ${ }^{8}$ Adapun terjemahan dari surat al'Anfal ayat 75 adalah sebagaimana berikut:

"Dan orang-orang yang beriman setelah itu kemudian berbijrah dan berjibad bersamamu, maka mereka termasuk golonganmu. Orangorang yang mempunyai bubungan kerabat itu sebagiannya lebih berhak terbadap sesamanya (daripada yang bukan kerabat) menurut kitab Allah. Sungguh Allah Maha mengetahui segala sesuatu."

Adanya ketentuan ayat di atas menunjukkan bahwa syariah Islam telah menetapkan aturan waris dengan bentuk yang sangat teratur dan adil. Di dalamnya ditetapkan hak kepemilikan harta bagi setiap manusia, baik laki-laki maupun perempuan sesuai dengan bagian masing-masing yang sudah ditetapkan. ${ }^{10}$ Hal ini sesuai dengan firman Allah dalam surat an-Nisa' ayat 7 yang artinya:

${ }^{5}$ Amir Syarifuddin, Hukum Kewarisan Islam, cet. I (Jakarta: Kencana, 2004), 5-6.

${ }^{6}$ Abdur Rahman I. Doi, Syariah II; Hudud dan Kewarisan, 99.

${ }^{7}$ Fatchur Rahman, Imu Waris (Bandung: PT Alma'arif, t.t), 11.

${ }^{8}$ Abdur Rahman I. Doi, Syariah II, 99- 100.

9 Departemen Agama RI, Al-Quran dan Terjemahnya; Al-Hikmah, cet. X (Bandung: CV Penerbit Diponegoro, 2010), 186.

${ }^{10}$ M. 'Ali al-Sabuni, Pembagian Waris Menurut Islam, terj. A.M. Basalamah, cet. I (Jakarta: Gema Insani Press, 1995), 32. 
"Bagi laki-laki ada hak bagian dari harta peninggalan kedua orang tua dan kerabatnya, dan bagi perempuan ada hak bagian (pula) dari harta peninggalan kedua orang tua dan kerabatnya, baik sedikit atau banyak menurut bahagian yang telah ditetapkan.",11

Ayat di atas juga menjelaskan tentang adanya hak pemindahan kepemilikan seseorang sesudah meninggal dunia kepada ahli warisnya dari seluruh kerabat dan nasabnya ${ }^{12}$ sesuai dengan bagian yang sudah ditetapkan.

Adapun yang menjadi sebab seseorang mendapatkan warisan/ menjadi ahli waris menurut Islam dapat diklasifikasikan sebagai berikut:

1. Adanya hubungan perkawinan

Adanya akad perkawinan yang sah menyebabkan suami isteri dapat saling mewarisi ${ }^{13}$ baik kematian salah satu suami atau isteri itu terjadi pada perkawinan ba'da dukhul atau qabla dukhul. ${ }^{14}$ Adapun yang mendasari sebab ini adalah firman Allah dalam surat an-Nisa' ayat $12^{15}$ yang artinya:

"Dan bagimu (suami-suami) adalah seperdua dari harta yang ditinggalkan oleh isteri-isterimu ......."

2. Adanya hubungan darah/ nasab

Seseorang dapat memperoleh harta warisan/ menjadi ahli waris disebabkan adanya hubungan kekerabatan dengan si mayit. Dasar dari sebab yang kedua ini adalah surat al-'Anfal ayat $75 .^{17}$ Adapun bunyi surat tersebut sebagaimana yang telah disebutkan sebelumnya.

3. Memerdekakan si mayit

Seseorang menjadi ahli waris disebabkan seseorang itu memerdekakan si mayit dari perbudakan, baik laki-laki

11 Departemen Agama RI, Al-Quran dan Terjemabnya, 78.

${ }^{12}$ M. 'Ali al-Sabuni, Pembagian W aris Menurut Islam, 32.

13 Salih Ahmad al-Syami, Al-Faraid; Fiqhan wa Hisaban, juz I (Beirut: al-Maktab al-Islami, 2008), 14.

14 Muhammad Muhyiddin Abdi al-Hamid, Abkam al-Mawaris; fi asy-Syari'ati alIslamiyyah (tt: Dar al-Kutub al-'Arabi, 1984), 15.

${ }^{15}$ Salih Ahmad al-Syami, Al-Faraid, 14 .

${ }^{16}$ Departemen Agama RI, Al-Quran dan Terjemabnya, 79.

${ }^{17}$ Sayyid Sabiq, Fiqh as-sunnah, juz 3 (Beirut: Dar al-Fikri: 2006), 1005. 
maupun perempuan. ${ }^{18}$ Adapun dasar pewarisan karena wala' adalah sabda Rasulullah ${ }^{19}$ yang artinya:

'Diceritakan dari Isma'il bin Abdullah, beliau berkata bahwa Malik telah menceritakan padaku (Isma'il) dari Nafi' dari Ibnu Umar bahwa Nabi SAW telah bersabda: "Sesunggubnya Waris wala' itu hanya bagi orang yang memerdekakannya". ${ }^{20}$

Golongan ahli waris yang telah disepakati hak warisnya terdiri atas 15 orang laki-laki dan 10 orang perempuan, dengan rincian sebagai berikut:

1. Kelompok ahli waris laki-laki terdiri dari anak laki-laki, cucu laki-laki pancar laki-laki dan seterusnya ke bawah, bapak, kakek shahih dan seterusnya ke atas, saudara laki-laki sekandung, saudara laki-laki sebapak, saudara laki-laki seibu, anak laki-laki saudara laki-laki sekandung, anak laki-laki saudara laki-laki sebapak, paman sekandung, paman sebapak, anak laki-laki paman sekandung, anak laki-laki paman sebapak, suami dan orang laki-laki yang memerdekakan budak.

2. Kelompok ahli waris perempuan terdiri dari anak perempuan, cucu perempuan pancar laki-laki dan seterusnya ke bawah ibu, nenek dari pihak bapak dan seterusnya ke atas, nenek dari pihak ibu dan seterusnya ke atas, saudara perempuan sekandung, saudara perempuan sebapak, saudara perempuan seibu, isteri dan orang perempuan yang memerdekakan budak. $^{21}$

Dari kedua puluh lima ahli waris tersebut dibedakan menjadi 3 kelompok, yaitu:

1. Ashabul furud yaitu para ahli waris yang mempunyai bagian tertentu yang telah ditetapkan oleh syara'. Adapun bagian yang

18 Suhrawardi K. Lubis dan Komis Simanjuntak, Hukum Waris Islam; Lengkap \& Praktik, cet. II (Jakarta: Sinar Grafika, 2008), 55-56.

${ }^{19}$ Ahmad Abdul Jawad, Usul; Ilm al-Mawaris (Beirut: Dar al-Ji, 1986), 3.

${ }^{20}$ Imam Abi Abdillah Muhammad bin Isma'il bin Ibrahim Ibnu al-Mugirah bin Bardazabah al-Bukhari al-Ja'fiyyi, Sabih al-Bukhari, juz 8 (Beirut: Dar al-Fikri, 2000), 11.

${ }^{21}$ Ahmad 'Abdu al-Jawad, Usul, 4. 
telah ditentukan tersebut ada enam, yaitu: $2 / 3,1 / 3.1 / 6,1 / 2$, $1 / 4$, dan $1 / 8 .^{22}$

2. 'Asabah yaitu ahli waris yang tidak mempunyai bagian tertentu, tetapi mereka menerima sisa pembagian setelah diambil oleh ahli waris ashabul furud. ${ }^{23}$

3. Zawil Arbam yaitu setiap kerabat yang tidak termasuk ashabul furud dan juga tidak termasuk golongan 'asabah. ${ }^{24}$

Adapun aturan pewarisan ketiga golongan ini adalah sebagai berikut:

1. Para ahli waris ashabul furud tersebut harus didahulukan dalam menerima bagian harta warisan daripada golongan 'asabab dan zawil arbam. Oleh karena itu, ada kemungkinan harta warisan dapat habis sama sekali ketika dibagikan kepada para ashabul furud sesuai dengan bagian masing-masing. Adapun jika masih ada sisa, maka sisa harta warisan inilah yang kemudian dibagikan kepada ahli waris 'asabah, sesuai dengan ketentuan yang ada.

2. Jika tidak ada seorang pun dari ahli waris ashabul furud, pembagian harta warisan dimulai dari para 'asabah bila mereka ada. Namun bila tidak ada, dialihkan kepada ahli waris zawil arbam. Demikian seterusnya menurut tertib orang-orang yang berhak menerima harta warisan. ${ }^{25}$

Akan tetapi, tidak selamanya ahli waris mendapatkan warisan dari si mayit karena ada kalanya terdapat hal-hal yang menyebabkan ahli waris tersebut kehilangan hak mewarisi. Adapun yang menjadi penyebab seseorang tidak mendapat harta warisan terdiri dari dua sebab, yaitu:

1. Adanya halangan kewarisan (mab $\}$ rum) yang meliputi:

a. Perbudakan

Seorang budak tidak cakap mengurus hak milik kebendaan dengan jalan apa saja sebagaimana firman Allah surat an-Nab\{l ayat $75,{ }^{26}$ yang artinya:

${ }^{22}$ Fatchur Rahman, Ilmu Waris, 128.

${ }^{23}$ Suparman Usman, Fiqih Mawaris Hukum, 65-66.

${ }^{24}$ Ibid., 80-81.

${ }^{25}$ Fatchur Rahman, Ilmu Waris, 131.

${ }^{26}$ Moh. Muhibbin, Hukum Kewarisan Islam, 75. 
"Allab membuat perumpamaan seorang hamba sabaya di bawah kekuasaan orang lain, yang tidak berdaya berbuat sesuatu......." 27

b. Pembunuhan

Perbuatan membunuh yang dilakukan oleh seorang ahli waris terhadap si pewaris menjadi penghalang baginya untuk mendapatkan warisan dari pewaris. Hal ini sesuai dengan hadis Nabi, yang artinya:

"Diceritakan dari Abu al-Hasan: Ali bin Abmad bin Abdan dari Ahmad bin 'Ubaid as\}s\}afar dari Ja'far bin Mubammad alFiryabi dari Ibrahim bin al-'Ala' dari Ismail bin 'Ayyas dari Ibn Juraij dari Amr bin Syu'aib dari ayahnya dari kakeknya berkata, Rasulullah SAW bersabda: "Tidak ada sedikitpun harta warisan bagi pembunuh" 28

c. Berlainan agama.

Jumhur ulama berpendapat bahwa seorang muslim tidak dapat mewarisi ataupun diwarisi oleh orang non muslim dengan dasar sabda Rasulullah yang artinya:

Diceritakan dari Musaddad dari Sufyan dari az-Zubriyyi dari 'Ali bin Husain dari Amr bin 'Usman dari Usamah bin Zaid, Rasulluh SAW bersabda: "Tidaklah berbak seorang muslim mewarisi seorang kafir, dan begitu pula orang kafir mewarisi muslim".

2. Adanya kelompok keutamaan (mahjub) yaitu hilangnya hak waris seseorang ahli waris disebabkan adanya ahli waris yang lebih dekat kekerabatannya atau lebih kuat kedudukannya. ${ }^{29}$ Adapun dalam Islam sendiri bijab itu dapat dibagi menjadi 2, yaitu:

a. Hijab nuqsan yaitu bergesernya hak seseorang ahli waris dari bagian yang besar menjadi bagian yang kecil, karena ada ahli waris lain yang mempengaruhinya.

${ }^{27}$ Departemen Agama, Al-Quran dan Terjemahnya, 275.

28 Suhrawardi K. Lubis dan Komis Simanjuntak, Hukum Waris Islam; Lengkap \& Praktik, 56.

${ }^{29}$ M. 'Ali al-Sabuni, Pembagian Waris Menurut Islam, 44. 
b. Hijab hirman yaitu hilangnya hak seorang ahli waris untuk seluruhnya, karena ada ahli waris yang lebih utama dari padanya. Dalam hal ini, anak laki-laki, anak perempuan, ibu, bapak, suami/ isteri tidak pernah ter-bijab sama sekali (ter-bijab birman), artinya dalam keadaan yang bagaimanapun mereka akan tetap memperoleh bagian dari harta warisan. ${ }^{30}$

\section{Ahli Waris Penerima Santunan Jasa Raharja}

Menurut UU No. 34 Tahun 1964, santunan Jasa Raharja adalah sejumlah uang yang akan dibayarkan dari dana yang terhimpun dari sumbangan wajib, yang dipungut setiap tahun dari para pemilik/ pengusaha alat angkutan lalu lintas jalan dan yang disediakan untuk menutup akibat keuangan karena kecelakaan lalu lintas jalan korban/ ahli waris yang bersangkutan. ${ }^{31}$

Sesuai dengan pasal 4 ayat 2 Peraturan Menteri Keuangan Nomor 36 /PMK.010/2008 tentang Besar Santunan dan Sumbangan Wajib Dana Kecelakaan Lalu Lintas Jalan, besar SWDKLLJ (Sumbangan Wajib Dana Kecelakaan Lalu Lintas Jalan) yang dipungut dari masing-masing pengusaha/ pemilik alat angkutan lalu lintas yaitu sebagai berikut:

1. Traktor, buldozer, forklift, mobil derek, excavator, crane dan sejenisnya dikenakan sumbangan wajib sebesar Rp. 20.000,00 (dua puluh ribu rupiah).

2. Sepeda motor, sepeda kumbang dan scooter di atas $50 \mathrm{cc}$ sampai $250 \mathrm{cc}$ serta kendaraan bermotor roda tiga dikenakan sumbangan wajib sebesar Rp. 32.000,00 (tiga puluh dua ribu rupiah).

3. Sepeda motor di atas 250 cc dikenakan sumbangan wajib sebesar Rp. 80.000,00 (delapan puluh ribu rupiah).

4. Pick up/ mobil barang sampai dengan $2400 \mathrm{cc}$, sedan, jeep dan mobil penumpang bukan angkutan umum dikenakan

${ }^{30}$ Suhrawardi K. Lubis, Hukum Waris Islam, 93

31 Presiden Republik Indonesia, "Undang-undang Republik Indonesia Nomor 34 Tahun 1964 Tentang Dana Kecelakaan Lalu Lintas Jalan," dalam bttp:/ / www.dpr.go.id/ un/ un1964/UU_1964_34.pdf(22 Oktober 2011), 1. 
sumbangan wajib sebesar Rp. 140.000,00 (seratus empat puluh ribu rupiah).

5. Mobil penumpang angkutan umum sampai dengan 1600 ee dikenakan sumbangan wajib sebesar Rp. 70.000,00 (tujuh puluh ribu rupiah).

6. Bus dan mikro bus bukan angkutan umum dikenakan sumbangan wajib sebesar Rp. 150.000,00 (seratus lima puluh ribu rupiah).

7. Bus dan mikro bus angkutan umum serta mobil penumpang angkutan umum lainnya di atas 1600 ee dikenakan sumbangan wajib Rp. 87.000,00 (delapan puluh tujuh ribu rupiah).

8. Truk, mobil tangki, mobil gandengan, mobil barang di atas 2400 ee, truk container dan sejenisnya dikenakan sumbangan wajib Rp. 160.000,00 (seratus enam puluh ribu rupiah)

Berbeda dengan jenis kendaraan yang telah disebutkan di atas, sepeda motor di bawah $50 \mathrm{cc}$, mobil ambulance, mobil jenazah dan mobil pemadam kebakaran dibebaskan dari kewajiban membayar SWDKLLJ. ${ }^{33}$

Sesuai dengan pasal 12 ayat 1 dan 2 PP No. 18 Tahun 1965, pembayaran Dana diberikan kepada:

1. Korban jika korban kecelakaan lalu lintas jalan, jika korban tersebut tidak meninggal dunia.

2. Ahli waris dari korban kecelakaan lalu lintas jalan, jika korban tersebut meninggal dunia. ${ }^{34}$

3. Yang menyelenggarakan penguburan korban mati akibat kecelakaan lalu lintas jalan, jika korban tersebut tidak

32 Menteri Keuangan Republik Indonesia, "Peraturan Menteri Keuangan Nomor 36 /PMK.010/2008 tentang Besar Santunan dan Sumbangan Wajib Dana Kecelakaan Lalu Lintas Jalan", dalam www.caplang.net/wpcontent/uploads/2008/04/pmk 36 2008.pdf (23 Oktober 2011), 3.

${ }_{33}$ Menteri Keuangan Republik Indonesia, "Peraturan Menteri Keuangan Nomor 36 /PMK.010/2008 tentang Besar Santunan dan Sumbangan Wajib Dana Kecelakaan Lalu Lintas Jalan", dalam www.caplang.net/wpcontent/uploads/2008/04/pmk 36 2008.pdf (23 Oktober 2011), 3.

34 Presiden Republik Indonesia, "Peraturan Pemerintah Republik Indonesia Nomor 18 Tahun 1965 Tentang Ketentuan-ketentuan Pelaksanaan Dana Kecelakaan Lalu Lintas Jalan", 9. 
mempunyai ahli waris yang tidak lain merupakan penggantian biaya-biaya penguburan. ${ }^{35}$

Adapun bunyi dari pasal tersebut adalah sebagai berikut:

(1) Yang berbak mendapat pembayaran Dana dalam hal kematian korban adalah jandanya/dudanya yang sab; dalam bal tidak ada jandanyal dudanya yang sah, anak-anaknya yang sab, dalam hal tidak ada jandanya/dudanya dan anak-anaknya yang sab, kepada orang-tuanya yang sah.

(2) Dalam hal korban tidak meninggal dunia, pembayaran Dana diberikan kepada korban. ${ }^{36}$

Pembayaran Dana yang akan diberikan kepada korban maupun ahli warisnya meliputi hal-hal berikut:

1. Korban meninggal dunia karena akibat langsung dari kecelakaan dalam waktu 365 hari setelah terjadinya kecelakaan yang bersangkutan.

2. Korban mendapat cacad tetap (anggota badannya hilang atau tidak dapat dipergunakan sama-sekali dan tidak dapat sembuh/ pulih untuk selama-lamanya) karena akibat langsung dari kecelakaan dalam waktu 365 hari setelah terjadinya kecelakaan yang bersangkutan.

3. Ada biaya-biaya perawatan dan pengobatan dokter yang diperlukan untuk korban karena akibat langsung dari kecelakaan dikeluarkan dari hari pertama setelah terjadinya kecelakaan, selama waktu paling lama 365 hari.

4. Korban mati tidak mempunyai ahli waris, maka diberikan penggantian biaya-biaya penguburan bagi yang menyelenggarakan penguburannya. ${ }^{37}$

Adapun yang berhak atas suatu pembayaran dari Dana Kecelakaan Lalu Lintas Jalan atau yang biasa disebut dengan santunan Jasa Raharja adalah pihak ketiga yaitu:

35 Ibid., 6.

36 Menteri Keuangan Republik Indonesia, ”Peraturan Menteri Keuangan Nomor 36 /PMK.010/2008 tentang Besar Santunan dan Sumbangan Wajib Dana Kecelakaan Lalu Lintas Jalan", 9.

37 Presiden Republik Indonesia, "Peraturan Pemerintah Republik Indonesia Nomor 18 Tahun 1965 Tentang Ketentuan-ketentuan Pelaksanaan Dana Kecelakaan Lalu Lintas Jalan”, 5. 
1. Setiap orang yang berada di luar angkutan lalu lintas jalan yang menimbulkan kecelakaan yang menjadi korban akibat kecelakaan dari penggunaan alat angkutan lalu lintas jalan tersebut, contoh: seorang pejalan kaki yang ditabrak oleh kendaraan bermotor.

2. Setiap orang yang berada di dalam suatu kendaraan bermotor dan ditabrak, dimana pengemudi kendaran bermotor yang ditumpangi dinyatakan bukan sebagai penyebab kecelakaan, termasuk dalam hal ini adalah para penumpang kendaraan bermotor dan sepeda motor pribadi.

Termasuk dalam golongan yang berhak atas santunan Jasa Raharja tersebut adalah seseorang yang berjalan kaki atau meyebrang di atas rel atau jalanan kereta api sehingga tertabrak kereta api, serta pengemudi/ penumpang kendaraan bermotor yang mengalami kecelakaan akibat lalu lintas perjalanan kerata api. Adapun dalam kasus tabrak lari, maka terlebih dahulu akan dilakukan penelitian atas kebenaran kasus kejadiannya.

Tidak selamanya orang-orang yang telah disebutkan di atas berhak atas santunan Jasa Raharja, karena terdapat beberapa ${ }^{\mathrm{P} e n y e b a b}$ seseorang kehilangan hak atas pembayaran santunan Jasa Raharja tersebut. Adapun penyebab yang dimaksud dapat dirinci sebagai berikut:

1. Penyebab tidak adanya santunan Jasa Raharja sesuai dengan pasal 13 PP No.18 Tahun 1965 yang berupa:

a. Jika korban/ ahli warisnya telah mendapat Dana Pertanggungan Wajib Kecelakaan Penumpang.

b. Kematian korban disebabkan atas kesengajaan dari pihak korban sendiri atau ahli warisnya, misalnya bunuh diri atau percobaan buuh diri.

c. Kecelakaan-kecelakaan yang terjadi pada waktu:

1) Korban sedang dalam keadaan mabuk atau tidak sadar, melakukan kejahatan, atau diakibatkan karena korban mempunyai cacad badan/ keadaan badaniah/ rokhaniah luar biasa lain.

2) Tidak langsung disebabkan oleh penggunaan kendaraan bermotor atau kereta api yang bersangkutan 
dalam fungsinya sebagai alat angkutan lalu lintas jalan. ${ }^{38}$

2. Penyebab gugurnya hak atas pembayaran santunan Jasa Raharja sesuai pasal 18 ayat (1) PP No. 18 Tahun 1965 yaitu berupa:

a. Jika tuntutan pembayaran Dana tidak diajukan dalam waktu enam bulan sesudah terjadinya kecelakaan lalulintas jalan yang bersangkutan.

b. Jika tidak diajukan gugatan terhadap Perusahaan pada pengadilan perdata yang berwenang dalam waktu enam bulan sesudah tuntutan pembayaran Dana ditolak secara tertulis oleh Direksi Perusahaan.

c. Jika hak atas pembayaran Dana tidak direalisasikan dengan suatu penagihan kepada Perusahaan atau kepada instansi Pemerintah atau pihak lain dalam waktu tiga bulan sesudah hak tersebut diakui, ditetapkan atau disahkan. ${ }^{39}$

Adapun besar santunan yang berhak diperoleh ahli waris dari korban yang meninggal dunia adalah sebesar Rp 25.000.000,00 (dua puluh lima juta rupiah). Hal ini sesuai dengan pasal 2 poin a Peraturan Menteri Keuangan Nomor 36 /PMK.010/2008 tentang Besar Santunan dan Sumbangan Wajib Dana Kecelakaan Lalu Lintas Jalan. Adapun bunyi pasal tersebut adalah sebagai berikut: "Ahli waris dari korban yang meninggal dunia berhak memperoleh santunan sebesar Rp 25.000.000,00 (dua puluh lima juta rupiah)."

Sedangkan penggantian biaya kepada pihak yang menyelenggarakan penguburan ketika korban kecelakaan lalu lintas jalan tidak memiliki ahli waris adalah sebesar Rp 2.000.000,00. Hal ini telah dijelaskan dalam pasal 3 Peraturan Menteri Keuangan Nomor 36 /PMK.010/2008 tersebut dengan bunyi: "Dalam hal korban meninggal dunia akibat kecelakaan alat angkutan lalu lintas jalan tidak mempunyai ahli waris, kepada pihak yang

38Presiden Republik Indonesia, "Peraturan Pemerintah Republik Indonesia Nomor 18 Tahun 1965 Tentang Ketentuan-ketentuan Pelaksanaan Dana Kecelakaan Lalu Lintas", 11.

${ }^{39}$ Ibid., 14-15. 
menyelenggarakan penguburan diberikan penggantian biaya penguburan sebesar Rp 2.000.000,00 (dua juta rupiah)."

Kebanyakan asuransi selain yang dikelola oleh Jasa Raharja menetapkan ahli waris berdasarkan kesepakatan yaitu berupa penunjukan oleh tertanggung terhadap beberapa ahli waris yang berhak atas klaim asuransi ketika meninggalnhya tertanggung. Hal ini berbeda dengan asuransi yang dikelola oleh Jasa Raharja dimana ahli warisnya telah ditetapkan berdasarkan aturan pemerintah yang tertuang dalam pasal 1 poin g PP No. 18 Tahun 1965 yaitu hanya anak-anak, janda/ duda, dan/ atau orang-tua dari korban mati kecelakaan lalu-lintas jalan.

Adapun bunyi pasal tersebut adalah sebagai berikut: "Ahliwaris ialah hanya anak-anak, janda/duda, dan/atau orang-tua dari korban mati kecelakaan lalu-lintas jalan sebagaimana dimaksudkan dalam pasal 12 Peraturan Pemerintah ini." ${ }^{41}$

Dalam pelaksanaan PP No. 18 Tahun 1965 oleh PT Jasa Raharja pengertian anak dan orang tua sah, tidak selamanya anak dan orang tua kandung, tetapi termasuk didalamnya adalah anak dan orang tua tiri serta anak dan orang tua angkat yang telah mendapat putusan dari pengadilan Negeri atau instansi berwenang lainnya. Bunyi dari aturan Jasa Raharja yang dimaksud adalah:

"Disamakan kedudukannya dengan anak dan orangtua sah

1. Pengertian dari anak dan orang tau sab tidak selalu pengertian anak kandung dan orang tua kandung, akan tetapi anak tiri dan orang tua tiri disamakan kedudukannya sebagai abli waris sab.

2. Demikian juga anak angkat dan orang tua angkat disamakan kedudukannya sebagai abli waris sab apabila telab mendapat putusan dari pengadilan Negeri atau instansi berwenang lainnya."

Adapun urutan ahli waris dalam hal penerimaan dana kecelakaan lalu lintas sesuai dengan pasal 12 ayat (1) PP No.18

40 Menteri Keuangan Republik Indonesia, "Peraturan Menteri Keuangan Nomor 36 /PMK.010/2008 tentang Besar Santunan dan Sumbangan Wajib Dana Kecelakaan Lalu Lintas Jalan", 3.

41 "Presiden Republik Indonesia, "Peraturan Pemerintah Republik Indonesia Nomor 18 Tahun 1965 Tentang Ketentuan-ketentuan Pelaksanaan Dana Kecelakaan Lalu Lintas Jalan", 2. 
Tahun 1965 sebagaimana yang telah disebutkan sebelumnya adalah sebagai berikut:

1. Janda atau dudanya yang sah.

2. Jika janda/ dudanya yang sah tidak ada, maka kepada anakanaknya yang sah.

3. Jika janda/ dudanya dan anak-anaknya yang sah tidak ada, maka kepada orangtuanya yang sah. ${ }^{42}$

Urutan penerimaan tersebut berbunyi: "Yang berhak mendapat pembayaran Dana dalam hal kematian korban adalah jandanya/ dudanya yang sah; dalam hal tidak ada jandanya/dudanya yang sah, anak-anaknya yang sah, dalam hal tidak ada jandanya/dudanya dan anak-anaknya yang sah, kepada orang tuanya yang sah." ${ }^{43}$

Sebagaimana yang telah dijelaskan bahwa apabila korban yang meninggal dunia akibat kecelakaan lalu lintas tidak mempunyai ahli waris tersebut di atas, maka diberikan akan diberikan penggantian biaya kepada pihak yang menyelenggarakan penguburan. ${ }^{44}$

\section{Penetapan Ahli Waris Penerima Santunan Jasa Raharja Perspektif Hukum Islam}

Sebelum menganalisis mengenai penetapan ahli waris dalam PP No. 18 Tahun 1965, terlebih duhulu harus dilakukan analisis terhadap kedudukan santunan Jasa Raharja dalam peraturan pemerintah tersebut, apakah santunan Jasa Raharja itu termasuk harta peningalan yang berhak diwarisi oleh ahli waris atau bukan. Sehingga dengan ditemukannya kedudukan santunan Jasa Raharja tersebut, akan memudahkan untuk menganalisis mengenai penetapan ahli warisnya pada langkah selanjutnya.

42 PT Jasa Raharja, "UU No 34 Tahun 1964 Jo PP No 18 Tahun 1965," dalam htp:/ / wmw.jasarabarja.co.id/ layanan/ lingkup-jaminan/ un-no-34-tabun-1964-jo-pp-no18-tabun-1965 (22 Oktober 2011).

43 Presiden Republik Indonesia, "Peraturan Pemerintah Republik Indonesia Nomor 18 Tahun 1965 Tentang Ketentuan-ketentuan Pelaksanaan Dana Kecelakaan Lalu Lintas", 9.

${ }^{44}$ Ibid., 6. 
Maurus atau harta warisan dalam Islam adalah harta benda yang ditinggalkan oleh si mayit yang akan dibagi oleh para ahli waris setelah diambil untuk biaya-biaya perawatan, melunasi hutang, dan melaksanakan wasiat. ${ }^{45}$ Pewarisan harta tersebut meliputi semua harta yang dimiliki berkaitan dengan harta kekayaan dan hak-hak lain yang tergantung kepadanya, misalnya utang piutang dan ganti rugi. ${ }^{46}$

Adapun santunan Jasa Raharja merupakan sejumlah uang yang akan dibayarkan dari dana yang terhimpun dari sumbangan wajib, yang dipungut setiap tahun dari para pemilik/ pengusaha alat angkutan lalu lintas jalan dan yang disediakan untuk menutup akibat keuangan karena kecelakaan lalu lintas jalan korban/ ahli waris yang bersangkutan. ${ }^{47}$

Dari kata "yang disediakan untuk menutup akibat keuangan karena kecelakaan lalu lintas jalan korban/ ahli waris yang bersangkutan" pada pengertian santunan Jasa Raharja, dapat dikatakan bahwa santunan tersebut merupakan sebuah ganti rugi yang diberikan akibat terjadinya suatu kecelakaan yang disebabkan oleh angkutan jalan. Santunan tersebut merupakan hak dari korban kecelakaan lalu lintas jalan dan akan beralih pada ahli waris jika korban kecelakaan lalu lintas jalan meninggal dunia.

Dengan diketahuinya bahwa santunan Jasa Raharja itu merupakan hak yang tergantung kepada korban meninggal akibat kecelakaan lalu lintas jalan, maka dapat disimpulkan bahwa santunan Jasa Raharja termasuk harta peninggalan yang merupakan hak dari ahli waris korban setelah diambil untuk biaya-biaya perawatan, melunasi hutang, dan melaksanakan wasiat.

Dalam PP No. 18 Tahun 1965 disebutkan bahwa yang dimaksud ahli waris hanya anak-anak, janda/duda, dan/ atau orang tua dari korban mati kecelakaan lalu-lintas jalan sesuai dengan bunyi pasal 1 poin g PP No. 18 Tahun 1965 yaitu: "Ahli waris ialah hanya anak-anak, janda/ duda, dan/ atau orang-tua dari korban

${ }^{45}$ Moh. Muhibbin, Hukum Kewarisan Islam, 57.

46 Abdur Rahman I. Doi, Syariah II, 98.

47 Presiden Republik Indonesia, "Undang-undang Republik Indonesia Nomor 34 Tahun 1964 Tentang Dana Kecelakaan Lalu Lintas Jalan” 1. 
mati kecelakaan lalu-lintas jalan sebagaimana dimaksudkan dalam pasal 12 Peraturan Pemerintah ini." 48

Adapun waris atau yang biasa dikenal dengan istilah ahli waris adalah orang-orang yang berhak mendapatkan harta peninggalan si mati, baik disebabkan ada hubungan kekerabatan dengan jalan nasab, pernikahan atau lainnya. ${ }^{49}$ Dengan demikian, ahli waris sebenarnya bukan hanya anak-anak, janda/ duda, dan/ atau orang tua sebagaimana yang ditentukan dalam PP No. 18 Tahun 1965.

Jika ahli waris penerima santunan Jasa Raharja yang terdiri dari anak-anak, janda/ duda, dan/ atau orang tua yang terdiri dari dilihat dari sudut pandang Islam, maka ahli waris tersebut dapat dikatagorikan sebagai berikut:

1. Ahli waris penerima santunan Jasa Raharja yang terdiri dari anak yang dalam hal ini hanyalah anak perempuan, orang tua (ibu/ bapak), serta janda/ duda atau bisa disebut suami atau isteri termasuk golongan ashabul furud yang mempunyai bagian tertentu yang telah ditetapkan oleh al-Qur'an.

2. Ahli waris penerima santunan Jasa Raharja yaitu anak laki-laki termasuk golongan 'asabah yang akan menerima sisa pembagian setelah diambil oleh ahli waris ashabul furud.

Adapun jika diperinci lebih lanjut, maka anak laki-laki merupakan golongan 'asabah nasabiyyah karena disebabkan oleh adanya hubungan darah dengan pewaris. Selain anak laki-laki, bapak disamping berkedudukan sebagai ashabul furud juga bisa berkedudukan sebagai 'asabah bila pewaris tidak meninggalkan anak atu cucu laki-laki. ${ }^{50}$

Tidak selamanya orang yang ditetapkan sebagai ahli waris sebagaimana yang telah disebutkan di atas selalu mendapatkan harta warisan. Secara garis besar yang menjadi sebab hilangnya hak kewarisan seseorang dapat diklasifikasikan menjadi dua, yaitu karena halangan kewarisan (mahrum) yang berupa pembunuhan,

48 Presiden Republik Indonesia, "Peraturan Pemerintah Republik Indonesia Nomor 18 Tahun 1965 Tentang Ketentuan-ketentuan Pelaksanaan Dana Kecelakaan Lalu Lintas Jalan", 2.

${ }^{49}$ M. 'Ali al-Sabuni, Hukum Waris dalam Syari'at Islam, terj. M. Samhuji Yahya (Bandung: Diponegoro, Cet. III, 1995), 47.

${ }^{50}$ Amir Syarifuddin, Hukum Kewarisan Islam, cet. I (Jakarta: Kencana, 2004), 234. 
perbudakan serta perbedaan agama dan karena adanya kelompok keutamaan $(\text { mahjub })^{51}$, yaitu adanya ahli waris yang lebih dekat kekerabatannya atau lebih kuat kedudukannya. ${ }^{52}$

Aturan Islam tersebut tentulah berbeda dengan aturan yang telah ditetapkan dalam PP No. 18 Tahun 1965 mengenai penyebab seseorang kehilangan hak atas pembayaran santunan Jasa Raharja yang meliputi penyebab tidak adanya santunan Jasa Raharja yang tertuang dalam pasal 13 PP No.18 Tahun 1965 dan penyebab gugurnya hak atas pembayaran santunan Jasa Raharja yang tertuang pasal 18 ayat (1) PP No. 18 Tahun 1965.

Telah dijelaskan sebelumnya bahwa jika korban mati akibat kecelakaan lalu lintas tidak memiliki ahli waris yang dalam hal ini hanya anak-anak, janda/duda, dan orang tua, maka bagi yang menyelenggarakan penguburan korban mati akibat kecelakaan lalu lintas tersebut diberikan penggantian biaya-biaya penguburan.

Berbeda dengan aturan yang telah ditetapkan dalam Islam bahwa jika tidak ada ahli waris yang tidak pernah ter-bijab hirman tersebut (anak-anak, janda/ duda, dan orang tua), maka harta tersebut di berikan kepada ahli waris selainnya, yang dimulai dari ahli waris dari golongan ashabul furud baru kemudian diberikan kepada golongan 'asabah dan zawil arbam pada urutan terakhir setelah kedua golongan sebelumnya tidak ada.

Selain itu, pengkatagorian anak dan orang tua tiri serta anak dan orang tua angkat yang telah mendapat putusan dari pengadilan Negeri atau instansi berwenang lainnya ke dalam golongan ahli waris juga tidak sesuai dengan ketentuan yang ada dalam hukum kewarisan Islam, karena dalam hukum kewarisan Islam anak dan orang tua tiri serta anak dan orang tua angkat telah mendapat putusan tersebut tidak termasuk golongan ahli waris.

Adapun biaya perawatan mayit yang termasuk didalamnya adalah biaya-biaya penguburan, terlebih dahulu harus diambil dari harta peninggalan mayit sebelum harta tersebut dibagikan kepada ahli waris yang berhak atas harta tersebut beserta dengan

${ }^{51}$ Suhrawardi K. Lubis, Hukum Waris Islam, 56.

${ }^{52}$ M. 'Ali al-Sabuni, Hukum Waris dalam Syari'at Islam, 43-44. 
pengambilan harta untuk melunasi hutang dan untuk melaksanakan wasiat.

Bagian Waris Jasa Raharja

Sesuai dengan pasal 12 ayat (1) PP No. 18 Tahun 1965, terdapat urutan dalam hal penerimaan dana kecelakaan lalu lintas, sehingga ketiga ahli waris yang telah ditentukan, menerima dana tersebut secara bergantian. Urutan penerimaan dana yang dimaksud adalah sebagai berikut:

1. Janda atau dudanya yang sah.

2. Jika janda/ dudanya yang sah tidak ada, maka kepada anakanaknya yang sah.

3. Jika janda/ dudanya dan anak-anaknya yang sah tidak ada, maka kepada orang tuanya yang sah. ${ }^{53}$

Dengan adanya urutan tersebut, maka dapat disimpulkan bahwa hanya salah satu dari ketiga ahli waris tersebut yang akan menerima keseluruhan santunan Jasa Raharja dan menghalangi secara penuh ahli waris penerima santunan Jasa Raharja yang lain untuk menerima santunan Jasa Raharja tersebut.

Telah dijelaskan bahwa ahli waris penerima santunan Jasa Raharja yang terdiri dari anak yang dalam hal ini hanyalah anak perempuan, orang tua (ibu/ bapak), serta janda/ duda termasuk golongan ashabul furud yang mempunyai bagian tertentu yang telah ditetapkan oleh syara'.

Adapun kedudukan ahli waris selainnya yaitu anak laki-laki termasuk golongan 'asabah yang akan menerima sisa pembagian setelah diambil oleh ahli waris ashabul furud. Selain anak laki-laki, bapak disamping berkedudukan sebagai ashabul furud juga berkedudukan sebagai 'asabah bila pewaris tidak meninggalkan anak atau cucu laki-laki. ${ }^{54}$

Dalam Islam telah diatur mengenai urutan pewarisan dari ketiga golongan yang ada yaitu dengan mendahulukan para ahli waris dari golongan ashabul furud dalam menerima bagian harta

53 Presiden Republik Indonesia, "Peraturan Pemerintah Republik Indonesia Nomor 18 Tahun 1965 Tentang Ketentuan-ketentuan Pelaksanaan Dana Kecelakaan Lalu Lintas", 9.

54 Amir Syarifuddin, Hukum Kewarisan Islam, 234. 
warisan. Jika masih ada sisa harta warisan, maka dibagikan kepada ahli waris 'asabab sesuai dengan ketentuan yang ada. Jika tidak ada ahli waris ashabul furud, pembagian harta warisan dimulai dari para asabah bila mereka ada dan diteruskan kepada ahli waris zawil arbam jika tidak ada golongan asabah. ${ }^{55}$

Dengan demikian, jika ditinjau dari segi Islam, maka ahli waris penerima santunan Jasa Raharja yang dalam hal ini adalah anak-anak, janda/ duda dan orang tua tidak selalu mewarisi secara bergantian, tetapi dapat mewarisi secara bersamaan sesuai dengan bagian masing-masing sesuai dengan surat al-Nisa' ayat 7 .

Jika diurutkan menurut Islam, maka urutan pewarisan ahli waris penerima santunan Jasa Raharja adalah sebagai berikut:

1. Santunan Jasa Raharja dibagikan terlebih dahulu kepada ahli waris penerima santunan Jasa Raharja yang termasuk golongan ashabul furud, yaitu anak perempuan, ibu, bapak, istri/suami dengan bagiannya masing-masing yang telah ditentukan oleh syara'.

2. Jika masih terdapat sisa setelah dibagikan kepada ahli waris yang termasuk golongan ashbul furud (yang dalam hal ini adalah anak perempuan, duda/ janda, orang tua), maka santunan Jasa Raharja tersebut kemudian dibagikan kepada ahli waris yang termasuk golongan asabah. Adapun urutan golongan asabab diantara ahli waris penerima santunan Jasa Raharja dalam menerima santunan Jasa Raharja tersebut adalah sebagai berikut:

a. Anak laki-laki yang pertama akan menerima sisa harta warisan tersebut.

b. Bapak akan menerima sisa harta warisan jika pewaris tidak meninggalkan anak atau cucu laki-laki.

Setiap ahli waris akan menerima harta warisan sesuai dengan bagian masing-masing yang telah ditentukan dan bagian-bagian yang akan diterima oleh ahli waris tersebut dapat berubah sesuai dengan jumlah dan siapa saja ahli waris yang ada.

\section{Penutup}

${ }^{55}$ Fatchur Rahman, Ilmu Waris, 131. 
Menurut PP No. 18 Tahun 1965, ahli waris hanyanyalah anak-anak, janda/ duda, dan/ atau orang-tua dari korban mati kecelakaan lalu-lintas jalan dengan aturan penerimaan pembayaran santunan dimulai dari jandanya/ dudanya yang sah, kemudian anak-anaknya yang sah, jika tidak ada janda/ dudanya yang sah dan diakhiri orang tuanya yang sah, jika janda/ dudanya serta anak-anak yang sah tidak ada.

Penetapan ahli waris dalam PP No. 18 Tahun 1965 tersebut tidak sepenuhnya menerapkan ketentuan hukum kewarisan Islam karena hanya memberikan santunan Jasa Raharja yang merupakan bagian harta waris kepada golongan ahli waris yang sama sekali tidak bisa ter-hijab birman, yaitu hanya janda/ duda, anak-anak dan orang tua.

Meskipun demikian, jika dilihat dari asal dana santunan Jasa Raharja yang bukan dari korban, namun terhimpun sumbangan wajib yang dipungut setiap tahun dari para pemilik/ pengusaha alat angkutan lalu lintas jalan, maka dapat dikatakan cukup adil jika santunan tersebut hanya diberikan kepada ahli waris sedarah yang mempunyai hubungan terdekat dengan korban saja. Keadilan yang dimaksud juga terlihat dari adanya penggantian biaya penguburan bagi korban yang tidak mempunyai ahli waris.

Oleh karena itu, idealnya ahli waris dalam PP No. 18 Tahun 1965 tersebut hanya dimaknai sebagai penerima awal santunan Jasa Raharja yang kemudian santunan tersebut tetap harus dicampurkan dengan harta peninggalan korban yang lain dan dibagikan kepada ahli waris korban setelah diambil untuk biaya-biaya perawatan, melunasi hutang dan melaksanakan wasiat. ${ }^{56}$

\section{Daftar Pustaka}

Abdul Jawad, Ahmad. Usul; Ilm al-Mawaris. Beirut: Dar al-Ji, 1986.

Doi, Abdur Rahman I. Syariah II; Hudud dan Kewarisan, terj. Zaimuddin, et al, cet. I. Jakarta: PT Raja Grafindo Persada, 1996.

Hamid (al), Muhammad Muhyiddin Abdi. Abkam al-Mawaris; fi asySyari'ati al-Islamiyyah. tt: Dar al-Kutub al-'Arabi, 1984.

${ }^{56}$ Moh. Muhibbin dan Abdul Wahid, Hukum Kewarisan Islam; Sebagai Pembaharuan Hukum Positif di Indonesia, (Jakarta: Sinar Grafika, 2009), 57. 
Ja'fiyyi (al), Imam Abi Abdillah Muhammad bin Isma'il bin Ibrahim Ibnu al-Mugirah bin Bardazabah al-Bukhari. Sabih al-Bukhari, Juz 8. Beirut: Dar al-Fikri, 2000.

Lubis, Suhrawardi K. dan Komis Simanjuntak. Hukum Waris Islam; Lengkap \& Praktik, cet. II. Jakarta: Sinar Grafika, 2008.

Muhibbin, Moh. dan Abdul Wahid. Hukum Kewarisan Islam; Sebagai Pembaharuan Hukum Positif di Indonesia. Jakarta: Sinar Grafika, 2009.

Rahman, Fatchur. Ilmu Waris. Bandung: PT Alma'arif, t.t.

Sabuni (al), M. 'Ali. Hukum Waris dalam Syari'at Islam, terj. M. Samhuji Yahya, cet. III. Bandung: Diponegoro, 1995.

Sabuni (al), M. "Ali, Pembagian Waris Menurut Islam, terj. A.M. Basalamah, cet. I. Jakarta: Gema Insani Press, 1995.

Sabiq, Sayyid. Fiqh as-sunnah, juz 3. Beirut: Dar al-Fikri: 2006.

Syami (al), Salih Ahmad Al-Faraid; Fighan wa H\}isaban, juz I. Beirut: al-Maktab al-Islami, 2008.

Syarifuddin, Amir. Hukum Kewarisan Islam, cet. I. Jakarta: Kencana, 2004.

Usman, Suparman dan Yusuf Somawinata. Fiqih Mawaris Hukum; Kewarisan Islam, cet. II. Jakarta: Gaya Media Pratama, 2002.

Departemen Agama RI. Al-Quran dan Terjemahnya; Al-Hikmah, cet.

X. Bandung: CV Penerbit Diponegoro, 2010.

Presiden Republik Indonesia. "Peraturan Pemerintah Republik Indonesia Nomor 18 Tahun 1965 Tentang Ketentuanketentuan Pelaksanaan Dana Kecelakaan Lalu Lintas Jalan," dalam http://dapp.bappenas.go.id/website/peraturan/file/pdf/P P 1965 018.pdf. 22 Oktober 2011.

Presiden Republik Indonesia. "Undang-undang Republik Indonesia Nomor 34 Tahun 1964 Tentang Dana Kecelakaan Lalu Lintas Jalan," dalam http://www.dpr.go.id/uu/uu1964/UU 1964 34.pdf. 22 Oktober 2011.

Menteri Keuangan Republik Indonesia. "Peraturan Menteri Keuangan Nomor 36 /PMK.010/2008 tentang Besar Santunan dan Sumbangan Wajib Dana Kecelakaan Lalu Lintas Jalan", dalam www.caplang.net/wp- 
content/uploads/2008/04/pmk 36 2008.pdf. 23 Oktober 2011.

PT Jasa Raharja. "UU No 34 Tahun 1964 Jo PP No 18 Tahun 1965," dalam

http://www.jasaraharja.co.id/layanan/lingkupjaminan/uu-no-34-tahun-1964-jo-pp-no-18-tahun-1965. 22 Oktober 2011. 